\title{
The emergence of black queer characters in three post-apartheid novels
}

\section{Grant Andrews}

\section{The emergence of black queer characters in three post-apartheid novels}

Before the end of apartheid, queer lives were almost entirely unrepresented in public literary works in South Africa. Only after the fall of institutionalised apartheid could literature begin to look back at the role of queer people in the history of South Africa, and begin to acknowledge that queer people are a part of the fabric of South African society. A number of celebrated authors emerged who were exploring queer themes; however, most of these authors and the stories they told were from a white perspective, and black queer voices were still largely absent in literature, especially novels. This paper explores the limited number of black queer literary representations following the influential work of K. Sello Duiker. I explore the social dynamics that might have influenced the fact that so few examples of black queer characters currently exist in South African literature. Through an analysis of novels by Fred Khumalo, Zukiswa Wanner, and Chwayita Ngamlana, I show how black, queer characters in post-apartheid novels confront ideas of culture, race, and sexuality as they wrestle with their identities and with questions of belonging and visibility. Keywords: African queer studies, post-apartheid literature, queer identity, queer studies, South African literature.

\section{Introduction}

In a system as imposing and horrifying as apartheid, the suppression of 'unwanted' voices is a necessary component. The apartheid state relied on propaganda to function, and the founding myth of independent racial and ethnic 'nations' that would only be able to optimally develop separately was the system's lifeblood. Ryan Richard Thoreson explains that "the official fear of racial mixing was closely tied to the preservation of the white, heterosexual, reproductive family, spawning unforgiving prohibitions - on miscegenation, homosexuality and non-procreative sexuality" (680). Any deviance from this official narrative was seen as threatening; any voices which resisted it were often violently silenced. ${ }^{1}$

Literature was one of the great victims of this silencing, and in light of the homophobia inherent in apartheid structures, queer literature suffered greatly. ${ }^{2}$ The reliance on a particular form of patriarchal masculinity, and the strict gender roles which complemented the project of separate development, purposely excluded queer voices and sought to oppress representations of queer lives. Same-sex desires and queer realities were consequently almost never represented in published literature during apartheid. While these voices have found expression in post-apartheid South Africa, there are still notable racial divides, and very few black queer characters and authors are included in discussions of recognised post-apartheid literature. ${ }^{3}$

This article explores queer voices and visibilities in South Africa in order to consider the dynamics which led to this dearth of black queer representations in literature. I briefly outline the queer rights movement during apartheid, and the tumultuous positioning of black activists like Simon Nkoli in fighting against apartheid but also fighting for gay and lesbian rights. I look at the silencing of queer voices within literature through censorship and social stigma, and how this silencing has been addressed in post-apartheid queer literature through a "retrospective cartography of the previously occluded queer nation" (Stobie, "Postcolonial pomosexuality: queer/alternative fiction after Disgrace" 320-1). These compounded silencings have led to black queer authors and characters still facing multiple barriers in post-apartheid South Africa. The extraordinary work of author K. Sello Duiker in the late 1990s and the early 2000s seemed to usher in a new era of queer black representation, and Duiker's novel The Quiet Violence of Dreams (2001) was at once revolutionary and a seemingly natural extension of the truth-telling and democratisation which the country was undergoing after the end of apartheid.

The themes of Duiker's novel are explored in this paper as a way to demonstrate the conflicts inherent in queer black fiction and to revisit the potential of what Duiker had produced. Unfortunately, Duiker's powerful

Grant Andrews is a postdoctoral research fellow in the English Department at Stellenbosch University, Stellenbosch, South Africa. His research interests include queer South African literature, film, and theory.

Email: gcandrews@gmail.com

(iD https://orcid.org/0000-0001-5268-0800

DOI: dx.doi.org/10.17159/2309-9070/tvl.v.56i2.5843 
literature has not led to the emergence of a great deal of queer black voices in South African literature, and his death in 2005 spelled the loss of one of the most dynamic young writers in the country. Since Duiker's breakthrough novel, there have been sporadic contemporary examples of authors exploring queer black characters in literature, at least in ways that were used to demonstrate diversity in the 'rainbow nation' or to explore questions of gender and sexuality in post-apartheid South Africa. A selection of three novels is discussed in this paper to demonstrate recent developments in queer black representation. Fred Khumalo's Seven Steps to Heaven (2007), Zukiswa Wanner's Men of the South (2010), and Chwayita Ngamlana's novel If I Stay Right Here (2017) will be briefly explored at the end of this paper to exemplify some of the recent queer black fiction in South Africa, and to show how representations have responded to social changes after the end of apartheid.

While scholars like Cheryl Stobie and Brenna M. Munro have done detailed, extensive studies of many South African texts representing queer realities, this paper will build on their work to investigate representations particularly of black queer characters in novels and how these texts function within and respond to historical context in recent years. Other black queer characters have been imagined within South African literature, such as in Lauren Beukes's futuristic science fiction novel Moxyland (2008) and the short story collections Queer Africa: New and Collected Fiction (2013) and Queer Africa 2: New Stories (2017). In addition, black queer lives have been represented in nonfiction works like Nkunzi Zandile Nkabinde's Black Bull, Ancestors and Me: My Life as a Lesbian Sangoma (2008). While these texts add to the mosaic of representations, the novels outlined above will be the primary focus of this paper in order to demonstrate the nuanced subjectivities afforded to black queer characters in these extended works of fiction. This paper is therefore not comprehensive, and does not explore every instance of black queer literary representation; instead, texts have been selected to demonstrate some of the dynamics of cultural and sexual identities in South African fiction. These representations in novels can provide an intimate look at how these characters understand their identities, their Africanness, and their sense of belonging within contemporary South Africa. When read within the context of the 'silencing' inherent in apartheid structures and rigid traditionalist cultural mores, they offer the opportunity for voicing realities which are often suppressed.

\section{The struggle for queer rights and the suppression of queer voices during apartheid}

The role of queer rights and queer visibility had always been contentious during apartheid. Sheila Croucher explains that "policing of sexual minorities was consistent with repressive apartheid ideology" (317) and opposition to repressive legal frameworks was scattered since the gay organisations within the country were divided, and "a staunchly apolitical stance continued to characterise white gay South Africa" (317). Although various queer groups existed, they were still racially divided, which resulted especially in the silencing of black queer voices. Additionally, these gay organisations were mostly unwilling to outright oppose apartheid. The Delmas Treason Trial in 1985 saw one of the most important conflicts within the liberation movement with regard to gay rights, as Simon Tseko Nkoli, a gay man and United Democratic Front activist, was among the twenty-two people charged with treason. Nkoli came out to his fellow activists, and was shunned by many who felt that his homosexuality somehow tarnished the image of the struggle against apartheid (Reid 29). Thoreson explains that "Nkoli publicly insisted upon the inseparability of the struggles against apartheid and homophobia, challenging his comrades in both movements to fight together" (680). One of the few gay organisations in the country at the time, the mostly white Gay Association of South Africa (GASA), decided not to support Nkoli, himself a member of GASA, during the treason trial. GASA received local and international scorn for the stance of trying to remain 'apolitical' in the face of the injustices of apartheid.

The conflicting dynamics of the South African gay rights movement demonstrate various forms of silencing: firstly, the silencing of queer realities in service of the 'purity' of the liberation movement; secondly, the political voicelessness of the gay rights movements against apartheid; and thirdly, the silencing of black concerns in the early gay organisations in the country which had mostly white membership.

Another form of silencing was found in the paternalistic censorship during apartheid. Queer fiction under apartheid faced severe censorship, and likewise queer visibilities were socially shunned, to the point where representations of queer lives were almost nonexistent in the country. For example, Michael Power's 1972 novel Shadow Game, about an interracial love affair between two men, was banned despite positive international reception. Furthermore, even though it was not banned, J.M. Coetzee's novel In the Heart of the Country (1977) depicting same-sex desire between the white character Magda and the black farmworker Klein-Anna, emerged as one of Coetzee's least-discussed novels, and the queer elements in the text were almost completely ignored by critics at the time 
(Briganti 42). This again indicates a type of silencing and the obscuring of a text that depicts queer themes.

Only after the unbanning of the ANC and other political parties, a moment which signalled the fall of formal apartheid, were queer voices given more space to find expression. ${ }^{4}$ Due to legal and social changes during the 1990s, these previously marginalised realities were finally given the chance to reach mainstream audiences. Transgressive and diverse voices were celebrated, and queer literatures were being released by major publishers.

What emerged was literature that gave nuanced, sensitive portrayals of queer identities and experiences within South Africa. In post-apartheid South Africa, even though the majority of South Africans still seem to be vehemently homophobic, a space was created for queer voices to find large-scale expression and for queer realities to be a part of the "rainbow nation," a phrase which Munro notes "encodes the intersection of multiculturalism and gay rights" (vii). Munro explains that public opinion in the early 1990s saw the acceptance of gay people as symbolic of a discourse of freedom which had swept the country, and that representations of queer lives were in some ways embraced because "the idea of gay rights [...] [made] South Africans feel modern and magnanimous as they watched, or took part in, multiple dramas of acceptance" (xxiv; emphasis in original).

\section{Queer literature and voicing silences}

In post-apartheid South Africa, authors have looked back at the lives of queer people during apartheid, offering a view of the history of South Africa that includes queer lives (Stobie, "Pomosexuality" 320-1). This reclamation of a past, a stake in the history of South Africa, allowed for queer characters to assert their belonging in the country and to voice the realities of queer South African lives. Asserting belonging in fiction was a form of "writing back" (Munro xxvi) against systems which sought to oppress queer people.

However, queer literature by black authors or the representation of black, queer characters is still rare, even in the post-apartheid milieu. Cultural factors might have limited black South Africans from writing about queer themes, as Stobie notes that "the appellation 'un-African' is used as a means of controlling variant sexualities, and punitive behavior includes beating, rape and even murder" ("Pomosexuality" 322). This social context could play a role in why black writers have largely resisted queer themes and, where there are queer characters in the works of black authors, they are often shown to have great conflict between their sexuality and their cultural heritage, as in the works of Wanner and Duiker discussed later in this paper.

Due to the conflicts highlighted above, black, queer writing seems to be charged with a political imperative. Barbara Boswell, in her introduction to the short story collection Queer Africa 2, writes that cultural and artistic expression can be sites of "resistance" (2) against oppressive homophobia on the African continent. Representation, particularly the type of representation that challenges concepts of the assumed incompatibility of same-sex sexualities and an essentialised 'Africanness,' are in many ways still viewed as politically important in the South African context. By asserting the black, queer subject and their place in South Africa, these texts offer vital counternarratives to widespread homophobia.

\section{K. Sello Duiker and The Quiet Violence of Dreams}

Duiker's novel serves as an important starting point for discussions of post-apartheid black queer representations. Debrota Pucherova asserts: "Duiker is the first South African novelist to create a black gay protagonist, whose quest for identity eventually brings him to see his homosexuality as an inalienable part of his African identity" (936). Tshepo reconciles his sexuality and embraces it as a form of celebrating his Africanness, despite the many tensions he faces like the homophobia of his father and the sense of exclusion he feels from white queer characters. The novel presents an important narrative during the transition from apartheid where such depictions of race and sexuality faced overwhelming barriers. As Nonhlanhla Dlamini explains while discussing the normalisation of queer desire in the novel, "apartheid permeated the public and private spheres of life including quotidian experiences. For example, it impinged on the type of love, objects of sexual desire, and bodies to be desired" (69). The novel offered a ground-breaking representation of sexuality, race, and desire in post-apartheid South Africa, and intersections between these categories are reimagined in ways that open spaces for self-expression and reworkings of stifling categories for the characters. Analysing the themes of Duiker's text can offer a useful point of comparison for the more recent queer black representations.

The novel is highly meditative, with the young characters spending long passages ruminating on their situations and describing their vivid dreams and multilayered subjectivities. This process of introspection and maturation can be linked to the time period of political uncertainty, where the confusion of the characters reflects 
a country still searching for a new identity when the oppressive apartheid regime, represented by Tshepo's cruel, violent father, is a dying, yet inescapable, reality. Michael Chapman explains that Tshepo's rejection of his father can be read symbolically as the young South African who "ditches the Father figures of the struggle years for [...] harrowing adventures" (3). Chapman sees the novel as indicative of a trend of "postindependence disillusionment" (3), where the utopic promise of the 'rainbow nation' and widespread acceptance do not materialise for the characters. This analysis highlights the process of individual identity formation within changing national systems. The characters in the text reimagine the possibilities of gender, race, sexuality, and social class within a changing country, and Tshepo uses this framework to find a sense of freedom and hope while accepting himself as a black, queer man.

Tshepo eventually becomes a sex worker at a massage parlour in Cape Town called Steamy Windows, and he connects with the mostly white queer characters in the space, feeling finally accepted for his same-sex desires. Viljoen notes that, for Tshepo, "[a] sense of family is finally regained [...] and the bond that exists among them, black and white, is likened to a pre-Raphaelite brotherhood, until racism exposes that sentiment as fraudulent" (50-1). Annie Gagiano adds that the brotherhood "has its own, racist, frayed edges" (74) despite seemingly being embracing of Tshepo and allowing him to inhabit his queer sexuality. Furthermore, the realisation echoes the trend that Pucherova identifies in post-apartheid South African novels which "[express] disillusionment with the fashionable middle-class multiculturalism that only disguises thriving racism, xenophobia, and homophobia" (937). Tshepo is still excluded because of his race, even in the seemingly embracing brotherhood where same-sex sexuality and intimacy are celebrated in almost religious terms.

Tshepo begins to notice how he is objectified and how his sexual appeal is reduced to fetishisation based on his race for the consumption of wealthy, white men. He becomes merely a "black stallion" (Duiker 204), as the massage parlour's owner Shaun calls him, or "Exotic Angelo" (333) as his line in a classifieds publication reads. He is no longer the son or brother to other gay men which he might have imagined himself to be. The sense of exclusion and exploitation which Tshepo experiences can be read as representative of how black, queer voices are seen as out of place in mainstream queer culture in South Africa, a trend which is still apparent today. ${ }^{5}$

However, despite his conflicts around race and the way that he is unable to truly be a part of the queer brotherhood, Tshepo directly challenges the assumed tensions between blackness and same-sex sexuality in one of his meditations:

I mean, people always say that black culture is rigid and doesn't accept things like homosexuals and lesbians. You know the argument-it's very unAfrican. It's a lot of crap. In my experiences that kind of thinking comes from urbanised blacks, people who've watered down the real origins of our culture and mixed it with Anglo-Saxon notions of the Bible. It's stupid to even suggest that homosexuality and lesbianism are foreign to black culture. (250)

Tshepo sees no conflict between his race and his sexuality, and he uses the period of self-exploration to develop a philosophy that integrates the different parts of his identity as almost inextricably connected. Tshepo sees this link between Africanness and same-sex desire as a philosophy that he applies to a country transitioning into democracy and experiencing a new sense of freedom. Pucherova notes that in the novel, "Gay desire is presented as liberation from aggressive heteronormative masculinity and an opportunity for the redefinition of the entire society" (937). Representing black queer sexuality in the way that Duiker does in his novel offers great subversive potential, and his enduring legacy is a testament to the impact that these types of representations can have.

\section{Seven Steps to Heaven, Men of the South, and If I Stay Right Here}

The three more recent novels under discussion speak to the themes highlighted in Duiker's text, reassessing the conflicts of black queer subjects in a country where queer people have found more public spaces for self-expression, particularly in urban centres. The texts all seem to demonstrate more integrated identities for their protagonists, who are still cognizant of the conflicts of culture and sexuality in South African black queer identities, but resist these conflicts vocally and with less internal anguish than Tshepo displayed in Duiker's novel. The queer characters find spaces, both internally and in their social environments, where they can express their desires and assert their queer identities.

Fred Khumalo's Seven Steps to Heaven was published in 2007, the year after the passage of the Civil Union Act in South Africa. The story follows two boys, Sizwe and Thulani, who grow up together in a township and form a deep bond. Sizwe becomes an author and decides to publish, as a work of fiction, the autobiographical novel 
which Thulani wrote. The novel explores the relationship which Sizwe later develops with Patrick, a sex worker and drug addict whom Sizwe meets at university, and who encourages him to pursue his writing career. Even though the story is set in the early 1990s, with the accompanying conflicts around race and class in the transitional South Africa leading up to the first democratic elections, there is an indication that the representation of sexuality might be much more modern.

Patrick is in a relationship with a female student, Thembi, when he first meets Sizwe. However, after Patrick tells Sizwe about being a sex worker, he breaks down in tears in Sizwe's room. Sizwe comforts him, which leads to the friends having sex. Sizwe reflects on this moment with an atemporal, meta-analytical approach which suggests that the homophobia that might have haunted him, and might have curbed his true feelings for his childhood friend Thulani which are only hinted at earlier in the text, seems not to exist when he finally crosses the boundary of same-sex sexuality with Patrick: "Much later, Sizwe lay on his back staring at the ceiling. He was waiting for the feelings of strangeness, of disgust, to engulf him. A century later, the feeling hadn't even quivered on the horizon" (152-3). This stance could link to Kgomotso Masemola's assessment that the novel "marshals allochthonous memory and transcultural intertextuality to the extent that race, gender and masculinities are represented through a multiplicity and temporality that are sophisticated enough to transcend and/or implode the binary oppositions between men and women, gay and "straight" (370). Sizwe seems to easily reconcile his sexual relationship with Patrick, as Stobie notes that the "shift into same-sexuality occasions no guilt or angst" ("Reading Bisexualities From a South African Perspective-Revisited" 485), and soon after this first encounter, the two move in together and live openly as a same-sex couple.

Later, Patrick suggests that Sizwe should write an article under the title "The Politics of Being Gay in the Black South African Community" (155), and explains that it "will get people talking, how this young, straight black dude suddenly finds the urge to come out unashamedly in the face of a barrage of vilifications and insults" (155). The labels 'gay' and 'straight' are both applied to Sizwe in Patrick's suggestion; he is a "straight black dude" who somehow "finds the urge to come out". This links to Masemola's analysis of the novel as blurring boundaries, and indicates a complex sexual identity which neither of the characters seems to want to crystallise. This fluidity is compounded by the fact that Sizwe was attracted to Patrick's ex-girlfriend, Thembi, and seems to easily transition to his first same-sex relationship when he had not acknowledged attraction towards men before.

The depiction of same-sex desire in the text has still proven controversial, and has been read in ways which reinforce the assumed incompatibility of blackness and same-sex sexuality. Literary scholar David Magege, in his doctoral dissertation at a major South African university, has echoed the ideas of the 'unAfricanness' of homosexuality in analysing the novel, with the contention that this representation in Khumalo's novel "threatens the very social fabric upon which the majority of the South African society has been constructed" (Magege 250). Magege argues that the same-sex and interracial relationships in the novel "amount to a complex denial of practiced social norms" (248) and that "[w]orse still those who indulge in the acts do not seem to have agency but find themselves performing the act" (250). Magege's reductive analysis divorces the characters from their sexual agency in service of racialised ideas of sexuality. Magege explains that "the only female character engaged in such kind [sic] of deviance is Sheree, a white woman. It is clear that Patrick and Sizwe indulge because of pressure to survive, not necessarily sexual desire as is the case with the German nationals [in the novel]" (250). Magege situates 'authentic' homosexuality outside of South Africa, with the German characters who pay Patrick for sex, and aligns it with whiteness. This analysis strips the characters in the text of their desire for same-sex sexual pleasure, negates the closeness they find with each other in their long-term relationship, and discounts the fluidity of their sexuality. It is telling that even in post-apartheid South Africa, such ideas can still find currency in scholarship about same-sex sexualities in literature.

Adding to this sense of tension around same-sex sexualities in the novel, Patrick imagines that Sizwe has suffered "a barrage of vilifications and insults" (Khumalo 155) about his sexuality, when the novel does not show this. There is no blatant homophobia shown towards Sizwe in the text, and despite Patrick's suggestion of the article Sizwe should write, showing that he assumes a great deal of conflict between blackness and same-sex desire, Sizwe does not express any such conflict.

In Zukiswa Wanner's Men of the South (2010), published three years after Khumalo's text, urban black masculinities are represented in ways that disrupt patriarchal conceptions of fatherhoods and men's societal roles, representing a stay-at-home father who is denigrated by his wife and a Zimbabwean immigrant who impregnates a South African woman in an attempt to gain citizenship in South Africa. The middle section of the novel focalises 
the character Mzilikazi, who is gay and a father to two children from his previous marriage to a woman. When women flirt with him, he imagines responding that he is gay, and he reflects: "But I cannot say that, of course. It would definitely be the death of my relationship with my father" (85). Even though Mzilikazi lives as an out gay man in Cape Town, he still fears disclosing his sexuality freely. The idea of homosexuality being an affront to the father echoes the concerns of Duiker's novel, where traditionalist and patriarchal cultural conceptions underpin the relationship between father and son. Mzilikazi, as a gay father, disrupts this positioning of fathers as propagators of stifling gender roles or custodians of heterosexuality. However, Mzilikazi still suffers from conflicts between his racial and cultural identity and his life as a gay man, reflected through the disapproval of his own father.

Mzilikazi particularly remembers his father's disdain towards the idea of same-sex marriage: "I remember watching the news with [my father] the one time. A clip about same-sex marriages having finally been permitted in South Africa by the Constitutional Court came on, and a look of disgust came over his face" (122). The passage of same-sex marriage legislation indicates the fundamental shifts which have occurred around the strict patriarchal conceptions in South African society. The law begins to recognise a multiplicity of realities which run counter to established gender norms, and this is met with resistance by fathers like Mzilikazi's.

He reflects on the fallacious appeals to authenticity which are captured in his father's reaction to same-sex marriage and how it is seen as 'unAfrican': "Deep down I thought of the hypocrisy of my father, talking of what is not African when he could not find it in him to embrace other Africans unless they were South Africans. Or talking of Christianity, at that, when he himself had not been to church since I was in Standard 5" (123). The challenges to sexual diversity on the grounds of religion and culture are thus used by Mzilikazi's father to maintain hierarchies of power in hypocritical ways. This realisation, and the fact that Mzilikazi can challenge stifling conceptions of religion and culture, shows the highly critical nature of the post-apartheid black queer character, a stance which was also evident in Tshepo in Duiker's novel and Sizwe in Khumalo's novel. These characters subvert and challenge ideas of culture and tradition, resist boundaries in their sexual identities, and take a great deal of agency in their self-definition.

When Mzilikazi moves to Cape Town, he experiences a new sense of freedom, finally finding both physical and psychic distance from his father. He escapes the influence of stifling patriarchal conceptions and begins to narrate his own life, reflecting: "Now I could be the person I always wanted to be, but downplayed because of my and society's skewed expectations of what an African man should be like" (127).

After his father dies, Mzilikazi begins to wrestle even more with how his sexuality conflicts with ideas of masculinity, tradition, and culture. He imagines that his father might see him in death, even allowing for the possibility that his father might understand the fact that he is gay, just like Tshepo in Duiker's novel finds a new appreciation for his father in death. At a ritual after his father's funeral where Mzilikazi is given his father's traditional weapons to signal that he has become the "man of the house", he reflects on his family members who perform the ritual:

I wonder how these snuff-taking, mqombothi-drinking uncles of mine would react if they were to know that the man of the house is gay? Would they still give me the weapons? Would my father turn in his grave if, looking from above [...] he got to know that his eldest son is not Zulu enough in his sense of the word? Or would he perhaps start having a good debate with some long-dead Zulu warrior on the untruths of how homosexuality is human and has nothing to do with Africanness or Zuluness? (150)

Mzilikazi is able to imagine his father finding acceptance for him being gay. He presents a multi-layered, dynamic version of masculine expression, incorporating both the traditions and expectations of his father as well as his own gay identity which his father disapproved of. By reconciling homosexuality as "human" and not in conflict with "Africanness or Zuluness", Mzilikazi imagines his father as reflecting the democratic values which allow him to live openly as a gay man in Cape Town in post-apartheid South Africa.

The final text under discussion is Chwayita Ngamlana's If I Stay Right Here, published in 2017. The novel depicts the abusive relationship between Shay, a student and a journalist for an online publication, and Sip, an ex-gang member whom Shay meets in prison shortly before Sip is released. The two young women find themselves quickly developing a close relationship and move in together once Sip is released from prison, but Sip soon becomes violent and controlling with Shay.

Interestingly, Shay symbolises the violence in their relationship through the image of the fist, and likens it to clenched fists raised in protest against repressive laws. She reflects, in one of the meditative sections of the 
novel: "In this place a fist represents strength, freedom and empowerment" (45). She conflates the violence in her relationship with the liberation movement, and imagines that the fist which has just struck her face is somehow paralleled with the fight for freedom in South African society.

The juxtaposition suggests a sense that the violence constitutes a perversion of liberation, a perversion of the freedom that both women ostensibly enjoy in post-apartheid South Africa as black, queer subjects. Shay was taught in school about the liberation leaders, how their fists signalled change, but the fists here seem to signal imprisonment with Sip. Simultaneously, and ironically, the fists represent a type of normalising of their relationship. They are two young, black women who are able to live together and publicly show affection for one another because of the struggle against oppression which had come before. Even the very act of emphasising the violence in their relationship, rather than the conflicts of culture, race, and sexuality, is a subversive moment. Primarily, their relationship is represented as violent and dysfunctional; the fact that it is a same-sex relationship is often secondary in the text.

This signals a major shift from the earlier texts under discussion. The characters, being young, urban black women, do not seem concerned with conflicts between their Africanness and their same-sex sexualities. Shay and Sip express their desires openly, as do the many other queer characters in the text, both male and female. The characters are all complex and conflicted in multiple ways, but hardly ever show tensions around the expectations of traditional cultural mores and their queer identities.

However, there is still a recognition in the text of the particular struggles that queer black women face in South Africa, especially the violences and patriarchal oppression which are everyday realities for many in the country. Sip recounts the violence she suffers when she trespasses on a rival gang's territory before she meets Shay. The rival gang members kill her friend and rape Sip, and use the moment to target Sip's non-normative gender expression. Sip tells Shay, in a quiet moment that the two of them share in their bed in Shay's flat: "I remember [the man who attacked me] saying he's about to show me that I'm a girl, not the boy that I think I am. 'Ek sal jou wys, ek sal jou wys,' (I'll show you, I'll show you) he kept saying while thrusting into me repeatedly. I had never felt dick before" (56-7).

The rival gang member tries to dominate Sip by quashing her masculine gender expression, and enacts a patriarchal power-dynamic by asserting that Sip is feminine. This moment shows that even though the queer characters in this text feel a relative sense of social freedom to express themselves openly, there are still forces which seek to oppress them, and they still deal with homophobia and the oppression of their queer identities in various ways.

However, the characters exhibit much less conflict about remaining closeted than earlier texts demonstrate. Sip and Shay experience a mixture of public reactions when they go shopping for clothes together. Some of the store assistants look at them with desire as they presumably are seen as representing a sexual fantasy to male onlookers. However, there are also disapproving looks, especially towards Sip who tries on traditionally male clothing in the shop: "We were this female couple that danced and kissed between racks, called each other 'baby' all the time, made sexual gestures, took pictures and then left" (61). It would be hard to imagine earlier black queer characters feeling comfortable enough to publicly express their desires or to practise gender nonconforming behaviours in the way that Sip and Shay are able to. While it is significant that these are female characters in contrast to the male characters represented in earlier texts, which might link to different expectations in terms of gender and sexuality, the shifts in representation are still significant. This moment, just like others in Ngamlana's novel where the characters openly show affection in public spaces, suggests changing social attitudes that allow for more openness for queer characters. The two women are proud of their relationship, and while they recognise social unease at certain points, they grate against these restrictions and perform their attraction in ways that challenge heteropatriarchy.

\section{Conclusion}

Duiker's novel provided a powerful template of a black, queer voice wrestling with identity in the democratic South Africa, and many of the later texts echo the tensions which Tshepo raised. However, the changing representations of black queer characters show a sense of a more accepting social climate, even when there are recurring moments of homophobia and unease around black same-sex sexualities. The way that characters wrestle with the assumed conflict between their Africanness and their same-sex desires in these texts is important, as it shows a recognition of the previously ignored and suppressed queer black identities and also demonstrates how 
significant the recent representations are in confronting social values and reflecting on social change. Sip and Shay signal a very decisive shift in queer black representations, in that their sexuality is shown to be significant in the text, but causes much less conflict for them than demonstrated in earlier texts. Yet, even though they are less conflicted, face less public resistance, and are therefore less afraid of expressing themselves and demonstrating their affection, they are still victimised and vulnerable. The future of black, queer representation might see further acknowledgement of changing attitudes in South Africa. There is still much space for representations which assert the voices of black queer individuals, be they authors or characters in texts.

\section{Notes}

1. See, for example, the history of anti-apartheid activist and Black Consciousness thinker Steve Biko who was killed in detention in Pretoria in 1977, as well as the many authors who were banned during apartheid like Earnest Cole, André Brink, and others.

2. By queer, I refer to individuals belonging to sexual and gender minority groups, or those with non-normative gender expressions and same-sex sexual behaviours, desires, and identities. 'Queer literature' refers to literature depicting queer characters, as well as literature with expressions or suggestions of same-sex desire.

3. The terms 'black', 'African', 'Africanness' and 'race' are used throughout this discussion. These are widely contested terms, and they are used in this article in ways that align with South African racial categories that still persist in the postapartheid milieu and to a large extent impact on the lives and experiences of South Africans (Seekings 2). The ways that characters in the texts define their own identities in terms of race will be prioritised in how they are framed in this discussion; the characters see themselves as black and African, and use these ideas to define their experiences. Broadly, in keeping with South African racial categories that are used in social and political contexts, the term 'black' is used in this discussion to refer to those people or characters who would identify with the racial majority in South Africa who are descended from indigenous African groups. 'Black' is often interchangeable with 'African', but the latter term, especially in relation to the idea of 'Africanness', also has links to the cultural heritage and traditional practices of black ethnic groups in the country. For more clarity on this racial category and the uses of the terms black and African in the South African context, see Seekings. The term 'identity' is used in relation to the way that characters define themselves in relation to being African, being queer, and being black.

4. The late 1980s saw the release of novels like those by Stephen Gray and films like Helen Nogueira's Quest for Love (1988) which represented queer realities. This was a time of great social upheaval in the country, and national states of emergency were declared in the period as the apartheid government struggled to cling to power. The period seemed to open the space for queer representations to begin to emerge. However, these examples were still incredibly rare and became more common after the major changes that came in 1990.

5. Many public queer spaces are still seen as exclusionary in terms of race. For example, the Johannesburg Pride Parade in 2012 saw the feminist group One in Nine disrupt the parade, and racist insults and even threats of violence were hurled at the mostly black protesters by the mostly white participants in the parade (Schutte). Cape Town also launched an Alternative Pride Parade after accusations that the mainstream Pride celebrations were racially exclusionary (DeBarros).

\section{Works Cited}

Beukes, L. Moxyland. Angry Robot, 2008.

Briganti, C. "A Bored Spinster with a Locked Diary: The Politics of Hysteria in In the Heart of the Country." Research in African Literatures vol. 25, no. 4, 1994, pp. 33-49.

Chapman, M. "African Literature, African Literatures: Cultural Practice or Art Practice?" Research in African Literatures vol. 34, no.1, 2003, pp. 1-10. DOI: https://doi.org/10.1353/ral.2003.0004.

Coetzee, J. M. In the Heart of the Country. Random House, 2004.

Croucher, S. "South Africa's democratisation and the politics of gay liberation." Journal of Southern African Studies vol. 28, no. 2, 2002, pp. 315-30. DOI: https://doi.org/10.1080/03057070220140720.

Duiker, K. S. The Quiet Violence of Dreams. Kwela, 2001.

DeBarros, L. "Cape Town Pride race row grows as Alternative Pride launched". https://www.mambaonline.com/2015/02/20/ cape-town-pride-race-debate-grows-alternative-pride-launched/. Accessed 18 Jul. 2018.

Dlamini, N. "Negotiating legitimacy and normalization of queer desires in Sello Duiker's The Quiet Violence of Dreams." Journal of the African Literature Association vol. 10, no. 1, 2016, pp. 68-79. DOI: https://www.tandfonline.com/doi/full/10.1080/2167473 6.2016.1199362.

Gagiano, A. "Adapting the National Imaginary: Shifting Identities in Three Post-1994 South African Novels." Journal of South African Studies vol. 30, no. 4, 2004, pp. 811-24. DOI: https://doi.org/10.1080/0305707042000313031.

Khumalo, F. Seven Steps to Heaven. Jacana 2007.

Magege, D. From Chinua Achebe to Fred Khumalo: the politics of black female cultural difference in seven literary texts. Diss. U of South Africa, 2016. http://hdl.handle.net/10500/22245.

Martin, K. \& M. Xaba, eds. Queer Africa: New and Collected Fiction. Modjaji, 2013. . Queer Africa 2: New Stories. Ma'Thoko's, 2017.

Masemola, K. "Transcultural memory and intertextuality in Fred Khumalo's Seven Steps to Heaven." Unisa School of Arts 2013 Conference Proceedings, 2014, pp. 370-79.

Munro, B. M. South Africa and the Dream of Love to Come: Queer Sexuality and the Struggle for Freedom. U of Minnesota P, 2012.

Nkabinde, N. Z. Black Bull, Ancestors and Me: My Life as a Lesbian Sangoma. Jacana, 2008.

Ngamlana, C. If I Stay Right Here. Jacana, 2017.

Power, M. Shadow Game. Penguin Classics, 1972. 
Pucherova, D. "Re-Imagining the Other: The Politics of Friendship in Three Twenty-First Century South African Novels." Journal of Southern African Studies vol. 35, no. 4, 2009, pp. 929-43. DOI: https://doi.org/10.1080/03057070903314218.

Reid, G. "Fragments from the Archives I." Sex and politics in South Africa. Eds. K. Martin, N. Wallace \& G. Reid. Juta, 2005, pp. $28-33$

Schutte, G. "Johannesburg's Gay Pride Parade: Not Much to Be Proud of." The South African Civil Society Information Service (SACSIA). 8 Oct. 2012. http://sacsis.org.za/site/article/1450. Accessed 18 Jul. 2018.

Seekings, J. "The Continuing Salience of Race: Discrimination and Diversity in South Africa." Journal of Contemporary African Studies, vol. 26, no. 1, 2008, pp. 1-25. DOI: https://doi.org/10.1080/02589000701782612.

Stobie, C. "Postcolonial pomosexuality: queer/alternative fiction after Disgrace." Current Writing: Text and Reception in Southern Africa vol. 21, no. 1-2, 2009, pp. 320-4l. DOI: https://doi.org/10.1080/1013929x.2009.9678324.

"Reading Bisexualities from a South African Perspective—Revisited." Journal of Bisexuality vol. 11, no. 4, 2011, pp. 480-87. DOI: https://doi.org/10.1080/15299716.2011.620822.

Thoreson, R. R. "Somewhere Over the Rainbow Nation: Gay, Lesbian and Bisexual Activism in South Africa." Journal of Southern African Studies vol. 34, no. 3, 2008, pp. 679-97. DOI: https://doi.org/10.1080/03057070802259969.

Viljoen, S. "Non-Racialism Remains a Fiction: Richard Rive's 'Buckingham Palace', District Six and K. Sello Duiker's The Quiet Violence of Dreams." The English Academy Review vol. 18, no. 1, 2001, pp. 46-53. DOI: https://doi.org/10.1080/10131750185310061.

Wanner, Z. Men of the South. Kwela, 2010. 